\title{
DESKRIPSI KEMAMPUAN BERPIKIR KRITIS SISWA PADA MATERI GARIS DAN SUDUT DI KELAS VII-d SMP NEGERI 7 KENDARI
}

\author{
Ketut Samsur Rohman ${ }^{1)}$, Arvyaty ${ }^{2)}$, Ikman $^{3)}$ \\ ${ }^{1)}$ Alumni Jurusan Pendidikan Matematika, ${ }^{2,3)}$ Dosen Jurusan Pendidikan Matematika \\ FKIP Universitas Halu Oleo. Email: ${ }^{1)}$ syamsurrohman91@ gmail.com; ${ }^{2)}$ Arvyaty@gmail.com; \\ 3)ikman_fkipmat@yahoo.com.
}

\begin{abstract}
Abstrak
Penelitian ini bertujuan untuk mengetahui Bagaimana deskripsi kemampuan berpikir kritis siswa pada materi garis dan sudut di kelas VII-d SMP Negeri 7 Kendari. Metode Penelitian ini adalah metode deskriptif kuantitatif. Hasil penelitian menunjukkan bahwa dari 24 siswa yang mengikuti tes diperoleh keterangan: (1) 3 atau 12\% siswa memiliki kemampuan berpikir kritis kriteria sangat kritis, (2) 8 atau 32\% siswa memiliki kemampuan berpikir kritis kriteria kritis, (3) 10 atau $40 \%$ siswa memiliki kemampuan berpikir kritis kriteria kurang kritis; dan (4) 3 atau 12\% siswa memiliki kemampuan berpikir kritis kriteria sangat kurang kritis. Dimana indikator kemampuan berpikir kritis yang dapat diselesaikan siswa diantaranya: (1) 12 siswa mampu menyelesaikan soal yang indikatornya mengidentifikasi, (2) 9 siswa mampu menyelesaikan soal yang indikatornya menghubungkan, (3) 6 siswa mampu menyelesaikan soal yang indikatornya menganalisis, (4) 11 siswa mampu menyelesaikan soal yang indikatornya memecahkan masalah, dan (5) 2 siswa yang mampu menyelesaikan soal yang indikatornya mengevaluasi.
\end{abstract}

Kata kunci: deskripsi, kemampuan, berpikir kritis.

\section{DESCRIPTION OF STUDENT CRITICAL THINKING ABILITY IN LINE AND ANGLE MATERIALS IN CLASS VII-D 7 KENDARI STATE SCHOOL}

\begin{abstract}
This study aims to find out how the description of students' critical thinking skills in line and angle material in class VII-d of SMP Negeri 7 Kendari. This research method is a quantitative descriptive method. The results showed that of the 24 students who took the test obtained information: (1) 3 or $12 \%$ of students had critical criterion critical thinking skills, (2) 8 or $32 \%$ of students had critical criterion critical thinking skills, (3) 10 or $40 \%$ of students have critical thinking skills that are less critical criteria; and (4) 3 or $12 \%$ of students have critical thinking skills that are critically less critical. Where indicators of critical thinking skills that can be completed by students include: (1) 12 students are able to solve the problem that the indicator identifies, (2) 9 students are able to solve the problem that the indicator connects, (3) 6 students are able to solve the problem the indicator analyzes, (4) 11 students are able to solve the problem that the indicator solves the problem, and (5) 2 students who are able to solve the problem that the indicator evaluates.
\end{abstract}

Keywords: description, ability, thinking critically. 


\section{Pendahuluan}

Pembelajaran didunia pendidikan saat ini sangat membutuhkan hal yang merangsang siswa aktif. Siswa dituntut mampu menyelesaikan masalah sendiri, mampu merangsang keinginannya sendiri untuk bertindak apa yang harus dan seharusnya dilakukan. Dengan motivasi belajar, siswa menjadi sangat aktif, bersemangat dan terlibat total dalam proses pembelajaran dan kegiatan dilakukan dengan keinginan untuk berkembang. Namun hal ini belum cukup untuk menjamin keefektifan apabila kondisi eksternal tidak mendukung.

Menurut Suherman (2008), dua hal penting yang merupakan bagian dari tujuan pembelajaran matematika adalah pembentukan sifat dengan berpikir kritis dan kreatif. Dengan berlandaskan kepada prinsip pembelajaran matematika yang tidak sekedar learning to know, melainkan juga harus meliputi learning to do, learning to be, hingga learning to live together, maka pembelajaran matematika harus bersandarkan pada pemikiran bahwa peserta didik harus belajar dan semestinya dilakukan secara komperhensif dan terpadu.

Soekamto (2001: 21) mendefinisikan belajar matematika sebagai suatu aktifitas mental untuk memahami arti dari hubunganhubungan dan simbol-simbol yang terkandung dalam matematika secara sistematik, cermat dan tepat, kemudian menerapkan konsep-konsep yang dihasilkan untuk memecahkan masalah dalam berbagai hal/keadaan/situasi nyata. Hasil belajar yang dicapai oleh siswa ditunjukkan oleh perubahan-perubahan dalam bidang pengetahuan/pemahaman, keterampilan, analisis, sintesis, evaluasi, serta nilai dan sikap. Perubahan yang dihasilkan dari belajar dapat berupa perubahan persepsi dan pemahaman, yang tidak selalu dilihat sebagai tingkah laku. Adanya perubahan itu tercermin dalam hasil belajar yang diperoleh siswa.

Johnson dan Rising mengatakan bahwa matematika adalah pola berpikir, pola mengorganisasikan, pembuktian yang logik, matematika itu adalah bahasa yang menggunakan istilah yang didefinisikan dengan cermat, jelas, dan akurat, representasinya dengan simbol dan padat, lebih berupa bahasa simbol mengenai ide daripada mengenai bunyi. James mengatakan bahwa matematika adalah ilmu tentang logika mengenai bentuk, susunan, besaran, dan konsep-konsep yang berhubungan satu dengan yang lainnya dengan jumlah yang banyak yang terbagi ke dalam tiga bidang, yaitu aljabar, analisis, dan geometri.

Jerome Brunner menyatakan bahwa belajar matematika akan lebih berhasil jika proses pengajaran anak diarahkan pada konsepkonsep dan struktur- struktur yang termuat dalam pokok bahasan yang diajarkan, disamping hubungan yang terkait antara konsep-konsep dan struktur-struktur tersebut. Tahapan belajar menurut Brunner: (1)Tahap enaktif, dalam tahap ini siswa secara langsung terlibat dalam memanipulasi objek, (2) Tahap ikonik, tahapan dimana kegiatan siswa berhubungan dengan mental, merupakan gambaran dari objek yang dimanipulasinya, dan (3) Tahap simbolik, tahapan dimana anak-anak memanipulasi simbol-simbol atau objek tertentu.

\begin{tabular}{cccc}
\multicolumn{2}{c}{ Kemampuan } & Berpikir & Kritis \\
merupakan salah satu tujuan dalam
\end{tabular} pembelajaran matematika. Pemerintah juga mengharapkan pembelajaran dirancang untuk membekali siswa dengan kemampuan berpikir kritis, sebagai kompetensi yang mendukung aktivitas sehari-hari dan dimasa akan datang (Kemendikbud, 2013). Berpikir kritis diperlukan untuk memeriksa kebenaran dari suatu informasi, sehingga dapat memutuskan informasi layak ditolak atau diterima (Kalelioglu \& Gulbahar, 2013; Asari, 2014). Dengan demikian, Kemampuan Berpikir Kritis penting untuk dikembangkan dalam suatu pembelajaran agar mampu memeriksa kebenaran informasi dan mengkomunikasikan ide yang mendukung keputusan.

Menurut Piaget setiap individu mengalami tingkat perkembangan kognitif yang teratur dan berurutan, mulai dari tingkat sensori motori (0-2 tahun), pra-oprasional (2-7 tahun), oprasional konkrit (7-11 tahun) dan oprasional formal (11 tahun keatas). Pada tingkat oprasional formal, berpikir kritis dapat dikembangkan.

Menurut Ruggiero (dalam As'ari, 2014) karakteristik pemikir kritis, antara lain jujur, mudah tertarik dan tertantang dalam memandang suatu masalah, berusaha keras untuk memahami dan meningkatkan rasa ingin tahunya, memberikan pendapat sesuai bukti dan mempertimbangkan ide-ide orang lain, serta berpikir sebelum bertindak. Kemampuan Berpikir Kritis adalah kemampuan yang 
membutuhkan pembelajaran dan latihan. Walaupun seseorang tidak dilahirkan dengan kemampuan untuk berpikir kritis, namun Kemampuan Berpikir Kritis dapat dikembangkan.

Berpikir Kritis memang tidak mudah, akan tetapi Kemampuan Berpikir Kritis dapat dipelajari dan dilatih (Kalelioglu \& Gulbahar, 2013; Facione, 2015). National Research Council (1989) menjelaskan bahwa memungkinkan berkembangnya Kemampuan Berpikir Kritis yaitu pengalaman-pengalaman individu yang diperolah melalui proses menyelesaikan masalah matematika. Dalam menyelesaian masalah matematis dapat membantu seseorang memahami informasi dengan baik.

Berpikir kritis membutuhkan banyak keterampilan, termasuk keterampilan mendengar dan membaca dengan hati-hati, mencari dan mendapatkan asumsi asumsi yang tersembunyi, dan menjajaki konsekuensi dari suatu pernyataan (Maxribbi, 2014).

Susanto (2015:92) menyatakan bahwa upaya untuk pembentukan Kemampuan Berpikir Kritis siswa yang optimal men-syaratkan adanya kelas yang interaktif, siswa dipandang sebagai pemikir bukan seorang yang diajar, dan pengajar berperan sebagaimediator, fasilitator, dan motivator yang membantu siswa dalam belajar bukan mengajar. Salah satu faktor yang menentukan keberhasilan pembentukan Kemampuan Berpikir Kritis siswa adalah keahlian dalam memilih dan menggunakan model pembelajaran yang tepat. Dengan model pembelajaran yang diterapkan diharap-kan siswa mampu membentuk, mengem-bangkan bahkan meningkatkan kemampuan berpikir kritis.

Menurut Trianto (2010:95), kemampuan berpikir adalah kemampuan untuk menganalisis, mengkritik, dan mencapai kesimpulan berdasar pada inferensi atau pertimbangan yang saksama. Iskandar (2009: 86-87) mengatakan bahwa kemampuan berpikir merupakan kegiatan penalaran yang reflektif, kritis, dan kreatif, yang berorientasi padasuatu proses intelektual yang melibatkan pembentukan konsep (conceptualizing), aplikasi, analisis, menilai informasi yang terkumpul(sintesis) atau dihasilkan melalui pengamatan, pengalaman, refleksi, komunikasi sebagai landasan kepada suatu keyakinan (kepercayaan) dantindakan. Selanjutnya, Rosyada (2004:170) mengungkapkan Kemampuan Berpikir Kritis (critical thinking) adalah menghimpun berbagai informasi lalu membuat sebuah kesimpulan evaluatif dari berbagai informasi tersebut. Inti dari Kemampuan Berpikir Kritis adalah aktif mencari berbagai informasi dan sumber, kemudian informasi tersebut dianalisis dengan pengetahuan dasar yang telah dimiliki peserta didik untuk membuat kesimpulan.

Berdasarkan teori perkembangan kognitif Piaget, anak seusia SMP belum sepenuhnya dapat berpikir abstrak, dalam pembelajarannya kehadiran benda-benda konkrit masih diperlukan. Meski begitu harus pula mulai dikenalkan benda-benda semi konkrit. Namun pada level SMP ini, anak sudah mulai dapat menerapkan pola berpikir yang dapat menggiringnya untuk memahami dan memecahkan permasalahan. Di sinilah peran berpikir kritis bagi anak usia SMP tersebut, yang dalam hal ini mengacu pada pendapat Piaget (mengenai ciri-ciri kemampuan kognitif anak pada level SMP), telah dapat diterapkan.

Ada dua hal tanda utama berpikir kritis menurut Hassoubah (2007: 87). Pertama adalah bahwa berpikir kritis adalah berpikir layak yang memandu ke arah berpikir deduksi dan pengambilan keputusan yang benar dan didukung oleh bukti-bukti yang benar. Kedua adalah bahwa berpikir kritis adalah berpikir reflektif yang menunjukkan kesadaran yang utuh dari langkah-langkah berpikir yang menjurus kepada deduksi-deduksi dan pengambilan keputusan-keputusan. Dalam matematika, proses berpikir tersebut merupakan bentuk suatu penalaran yang meliputi penalaran induktif dan penalaran deduktif. Penalaran induktif merupakan suatu proses berpikir untuk menarik kesimpulan atau membuat suatu pernyataan baru yang bersifat umum (general) berdasar pada beberapa pernyataan khusus yang diketahui benar. Sedangkan penalaran deduktif adalah suatu cara penarikan kesimpulan dari pernyataan atau fakta-fakta yang dianggap benar dengan menggunakan logika, sehingga kebenarannya lebih absolute.

Dari hasil observasi peneliti yang dilaksanakan pada bulan Desember 2017, menunjukkan bahwa pembelajaran Matematika di kelas VII SMP Negeri 7 Kendari masih belum dapat memaksimalkan Kemampuan Berpikir Kritis siswa. Model pembelajaran yang diterapkan guru belum melibatkan siswa secara aktif dan soal-soal matematika yang diberikan guru kepada siswa belum memungkinkan siswa 
untuk mengerjakan dalam berbagai cara serta sistematis. Hal ini dapat diidentifikasi dari kegiatan pada saat guru menjelaskan materi didepan kelas. Guru masih menerapkan pembelajaran konvensional dimana guru yang menjelaskan materi dan siswa memperhatikan saja. Padahal berdasarkan wawancara dengan guru, kemampuan matematika siswa kelas VII SMP Negeri 7 Kendari tergolong baik dan siswa cukup aktif bertanya di dalam proses pembelajaran serta siswa tidak kesulitan mengerjakan soal matematika. Namun, mereka tidak dapat untuk mengkomunikasikan ide-ide matematika mereka baik secara lisan maupun secara tulisan. Mereka juga tidak maksimal dalam menganalisis soal matematika. Hal tersebut dapat diidentifikasi dari bagaimana siswa menyelesaikan soal yang diberikan guru ketika pembelajaran berlangsung. Siswa cenderung langsung menuliskan hasil akhir dari soal yang diberikan guru, tanpa disertai dengan cara yang sistematis.

Selanjutnya, Bhisma Murti (2009) menguraikan beberapa karakteristik dari berpikir kritis yaitu:

1. Mengemukakan pertanyaan-pertanyaan dan masalah penting, merumuskannya dengan jelas dan teliti.

2. Memunculkan ide-ide baru yang berguna dan relevan untuk melakukan tugas. Pemikiran kritis memiliki peran penting untuk menilai manfaat ide-ide baru, memilih ide-ide yang terbaik, atau memodifikasi ideide jika perlu.

3. Mengumpulkan dan menilai informasiinformasi yang relevan, dengan menggunakan gagasan abstrak untuk menafsirkannya dengan efektif.

4. Menarik kesimpulan dan solusi dengan alasan yang kuat, bukti yangkuat, dan mengujinya dengan menggunakan kriteria dan standar yang relevan.

5. Berpikir terbuka dengan menggunakan berbagai alternatif sistem pemikiran, menilai, dan mencari hubungan-hubungan antara semua asumsi, implikasi, akibatakibat praktis.

6. Mampu mengatasi kebingungan, mampu membedakan antara fakta, teori, opini, dan keyakinan.

7. Mengkomunikasikan dengan efektif kepada orang lain dalam upaya menemukan solusi atas masalah-masalah kompleks, tanpa terpengaruh oleh pemikiran orang lain tentang topik yang bersangkutan.

8. Jujur terhadap diri sendiri, menolak manipulasi, memegang kredibilitas dan integritas ilmiah, dan secara intelektual independen, imparsial, netral.

Adapun jenis-jenis pemikiran kritis menurut Iskandar (2009: 88) antara lain adalah membandingkan dan membedakan (compare and contrast), membuat kategori (categorization), menerangkan sebab akibat (cause and effect), meneliti bagian dan hubungan bagian yang kecil dengan keseluruhan, membuat andaian, membuat ramalan dan inferensi.

Kaitannya dengan pendidikan matematika, menurut Sumarmo (2010: 4) secara umum berpikir matematik dapat diartikan sebagaicara Berpikir berkenaan dengan proses matematika (doing math) atau cara Berpikir dalam menyelesaikan tugas matematik (mathematical task) baik yang sederhana maupun yang kompleks. Ditinjau dari kedalaman atau kompleksitas yang terlibat, berpikir matematik dapat dibedakan atas: berpikir tingkat rendah (low-order thinking), berpikir tingkat rendah (medium-order thinking), dan berpikir tingkat tinggi (high-order thinking).

Kemampuan Berpikir Kritis matematik siswa merupakan Kemampuan seorang siswa dalam menyelesaikan suatu permasalahan dengan Kemampuan Berpikir yang melalui berbagi tahapan pemikiran. Mayadiana (2005:6) mengungkapkan Kemampuan Berpikir Kritis dalam matematika meliputi Kemampuan Menggeneralisasi dan mempertimbangkan generalisasi, mengidentifikasi, relevansi, merumuskan masalah kedalam model matematika, mereduksi dengan menggunakan prinsip, memberikan contoh soal penarikan kesimpulan dan merekonstruksi argumen. Kemampuan matematik menjadikan siswa menjadi lebih baik dalam menyelesaikan permasalahan yang dihadapi. Rath et al dalam Sudaryanto (2011) menyatakan bahwa salah satu faktor yang dapat mempengaruhi perkembangan Kemampuan Berpikir Kritis adalah interaksi antara pengajar dan siswa. Jadi, Kemampuan Berpikir Kritis matematik adalah kemampuan dalam menyelesaikan permasalahan menggunakan tahapan-tahapan pemikiran yang matematik dan tahapan-tahapan Kemampuan Berpikir Kritis matematik dapat diukur dengan 
menggunakan indikator-indikator Kemampuan Berpikir Kritis matematik. Sehingga proses pembelajaran dalam penelitian ini, melalui pemberian tantangan atau masalah kontekstual nonrutin kepada Siswa dan belajar secara individual atau kelompok, siswa diharapkan akan dapat meningkatkan Kemampuan Berpikir Kritis Matematik.

Menurut Ennis (1996) terdapat enam elemen dasar dalam Berpikir Kritis yaitu:

a. Focus (fokus), yaitu hal pertama yang harus dilakukan untuk mengetahui informasi. Untuk fokus terhadap permasalahan, diperlukan pengetahuan. Semakin banyak pengetahuan yang dimiliki akan semakin mudah mengenali informasi.

b. Reason (alasan), yaitu mencari kebenaran dari pernyataan yang akan dikemukakan. Dalam mengemukakan pernyataan harus disertai alasan-alasan yang mendukung pernyataan tersebut.

c. Inference (membuat pernyataan), yaitu mengemukakan pendapat dengan alasan yang tepat.

d. Situation (situasi), yaitu kebenaran dari pernyataan tergantung situasi yang terjadi. Oleh karena itu, perlu mengetahui situasi/keadaan permasalahan.

e. Clarity (kejelasan), yaitu memastikan kebenaran sebuah pernyataan dari situasi yang terjadi.

f. Overview (tinjauan ulang), yaitu melihat kembali sebuah proses dalam memastikan sebuah kebenaran pernyataan dalam situasi yang ada sehingga bisa menentukan keterkaitan dengan situasi lainnya.

Sehubungan dengan pendekatan pembelajaran dalam penelitian ini maka indikator yang digunakan dalam mengkaji Kemampuan Berpikir Kritis matematik siswa adalah kemampuan siswa dalam mengidentifikasi konsep, menghubungkan antar konsep, mengevaluasi, memecahkan masalah, dan menganalisis (Izmaimuza, 2010: 64). Kelima aspek tersebut diuraikan lebih lanjut di bawah ini:

1) Menganalisis merupakan suatu keterampilan menguraikan sebuah struktur ke dalam komponen-komponen agar mengetahui pengorganisasian struktur tersebut. Aspek menganalis meliputi: menuliskan apa yang diketahui dan ditanyakan dari soal.

2) Mengidentifikasi konsep merupakan menguraikan dan memahami berbagai aspek secara bertahap agar sampai kepada suatu formula baru. Aspek mengidentifikasi konsep meliputi: dapat menentukan/konsep/definisi/teorema dalam menyelesaikan permasalahan dengan jelas dan tepat.

3) Menghubungkan antar konsep merupakan menggabungkan bagian-bagian menjadi sebuah bentukan atau susunan yang baru. Aspek menghubungkan konsep meliputi: dapat menerapkan konsep/definisi/teorema dalam menyelesaikan masalah.

4) Memecahkan masalah secara matematis merupakan aplikasi konsep kepada beberapa pengertian baru. Aspek memecahkan masalah meliputi: menunjukan hasil utama dan prosedur dalam penyelesaian masalah/penentuan solusi/jawaban.

Mengevaluasi merupakan memberikan penilaian tentang nilai yang diukur dengan menggunakan standar tertentu. Aspek mengevaluasi meliputi: menguji kembali solusi/jawaban dan menentukan kesimpulan dari suatu permasalahan.

Bertitik tolak pada paparan yang ada, maka penulis berencana untuk mengadakan suatu penelitian dengan judul "deskripsi kemampuan berpikir kritis siswa pada materi garis dan sudut di kelas VII SMP Negeri 7 Kendari".

\section{Metode}

Metode yang digunakan dalam Penelitian ini adalah Metode Deskriptif Kuantitatif. Pemilihan Metode Deskriptif Kuantitatif tersebut didasari oleh tujuan Peneliti yang ingin mengetahui secara mendalam tentang Deskriptif Kemampuan Berpikir Kritis Siswa Pada Materi Garis dan Sudut di Kelas VII SMP Negeri 7 Kendari.

Penelitian ini dilaksanakan di SMP Negeri 7 Kendari, yang Beralamat di Jalan Pendidikan Kelurahan Anggalomelai Kecamatan Abeli Kota Kendari, Provinsi Sulawesi Tenggara. Pemilihan lokasi ini berdasarkan pada pertimbangan berikut. 
1) Memudahkan terciptanya Kolaborasi antara Peneliti dengan Kepala Sekolah dan Guru Mata Pelajaran Matematika.

2) Hasil wawancara dengan Guru Mata Pelajaran Matematika yang menyatakan bahwa belum pernah diadakan penelitian tentang Kemampuan Berpikir Kritis Siswa SMP Negeri 7 Kendari.

Subjek penelitian ini adalah siswa kelas VII-d di SMP 7 Kendari tahun pelajaran 2017/2018. Keseluruhan jumlah siswa kelas VII di SMP Negeri 7 Kendari berjumlah 97 siswa yang tersebar dalam 4 kelas yakni: kelas VII-a, VII-b, VII-c, dan VII-d. Dalam penelitian ini dipilih satu kelas yaitu kelas VII-d yang dilaksanakan pada tanggal 17 April - 5 Mei 2018. Pemilihan jumlah Subjek ini dilakukan dengan teknik Purposive Sampling. Purposive sampling adalah teknik untuk menentukan subjek penelitian dengan beberapa pertimbangan tertentu yang bertujuan agar data yang diperoleh nantinya bisa lebih refresentatif (Sugiyono:2010). Alasan menggunakan teknik Purposive Sampling adalah karena tidak semua sampel memiliki kriteria yang sesuai dengan fenomena yang diteliti. Oleh karena itu, penulis memilih teknik Purposive Sampling yang menetapkan pertimbangan-pertimbangan atau kriteria-kriteria tertentu yang harus dipenuhi oleh sampel-sampel yang digunakan dalam penelitian ini.

Penelitian ini menggunakan instrumen tes Kemampuan Berpikir Kritis siswa pada materi garis dan sudut di kelas VII-d SMPN 7 Kendari.

Instrumen penelitian berupa tes tertulis dalam bentuk uraian sebanyak 6 nomor pada materi garis dan sudut yang disusun oleh peneliti bekerja sama dengan guru bidang studi matematika kelas VII-d SMP Negeri 7 Kendari dan telah dikonsultasikan serta disetujui terlebih dahulu oleh dosen pembimbing.

Instrumen Kemampuan Berpikir Kritis matematik untuk uji panelis ini terdiri dari: (1) definisi konsep, (2) definisi operasional, (3) kisi-kisi dan (4) pertanyaan (soal essay) (Muljono, 2004: 139). Instrumen Kemampuan Berpikir Kritis matematik sebelum digunakan pada penelitian sesungguhnya, terlebih dahulu dianalisis validitas dan reliabilitasnya melalui panelis.

Untuk kriteria penilaian panelis sebagai berikut:
1) Kesesuaian antara butir soal dengan kompetensi dasar dan standar kompetensi

2) Kesesuaian antara butir soal dengan indikator.

3) Penggunaan Bahasa Indonesia yang benar.

4) Tidak bermakna ganda.

Adapun ketentuan penilaian panelis adalah sebagai berikut:

Skor 1, Jika dalam pertanyaan tidak satupun kriteria yang muncul

Skor 2, Jika dalam pertanyaan ada satu kriteria yang muncul

Skor 3, Jika dalam pertanyaan ada dua kriteria yang muncul

Skor 4, Jika dalam pertanyaan ada tiga kriteria yang muncul

Skor 5, Jika dalam pertanyaan semua kriteria muncul

Definisi Konseptual untuk Kemampuan Berpikir Kritis adalah kemampuan menggeneralisasi, mengidentifikasi, merumuskan masalah kedalam model matematika, mereduksi dengan menggunakan prinsip, penarikan kesimpulan dan merekonstruksi argumen.

Adapun Definisi Operasional untuk Kemampuan Berpikir Kritis adalah suatu kemampuan matematis yang mencerminkan dapat menganalisis permasalahan, mengidentifikasi konsep, menghubungkan antar konsep, memecahkan masalah dan mengevaluasi.

Kompetensi Inti Kisi-Kisi Instrumen penelitian ini antara lain:

1. Menghargai dan menghayati ajaran agama yang dianutnya.

2. Menghargai dan menghayati perilaku jujur, disiplin, tanggungjawab, peduli (toleransi, gotong royong), santun, percaya diri, dalam berinteraksi secara efektif dengan lingkungan sosial dan alam dalam jangkauan pergaulan dan keberadaannya

3. Memahami dan menerapkan pengetahuan (faktual, konseptual, dan prosedural) berdasarkan rasa ingin tahunya tentang ilmu pengetahuan, teknologi, seni, budaya terkait fenomena dan kejadian tampak mata.

4. Mengolah, menyaji, dan menalar dalam ranah konkret (menggunakan, mengurai, 
merangkai, memodifikasi, dan membuat) dan ranah abstrak (menulis, membaca, menghitung, menggambar, dan mengarang) sesuai dengan yang dipelajari di sekolah dan sumber lain yang sama dalam sudut pandang/teori.

Kompetensi dasar dan Indikator pencapaian Kompetensi ialah:

1. Menghargai dan menghayati ajaran agama yang dianutnya, Indikator pencapaiannya Bersemangat dalam mengikuti pembelajaran matematika.

2. Memiliki rasa ingin tahu, percaya diri, dan ketertarikan pada matematika serta memiliki rasa percaya pada kegunaan matematika, yang terbentuk melalui pengalaman belajar, Indikator pencapaiannya Suka bertanya selama proses pembelajaran dan Berani presentasi di depan kelas.
3. Memahami berbagai konsep dan prinsip garis dan sudut dalam pemecahan masalah nyata, Indikator pencapaiannya Menentukan jenis-jenis sudut, Menentukan besar sudut-sudut berpelurus dan berpenyiku, Menentukan semua pasangan sudut yang terbentuk jika dua garis sejajar dipotong garis lain, dan Menentukan besar suatu sudut pada dua garis sejajar yang dipotong garis lain jika diketahui besar sudut yang lainnya.

4. Menerapkan berbagai konsep dan sifatsifat terkait garis dan sudut dalam pembuktian matematis serta pemecahan masalah nyata, Indikator pencapaiannya Menerapkan berbagai konsep dan sifatsifat sudut dalam pemecahan masalah nyata.

Tabel 1.

Kisi-Kisi Tes Kemampuan Berpikir Kritis

\begin{tabular}{|c|c|c|}
\hline Indikator Pencapaian & $\begin{array}{c}\text { Indikator Kemampuan } \\
\text { Berpikir Kritis }\end{array}$ & $\begin{array}{c}\text { Nomor } \\
\text { Soal }\end{array}$ \\
\hline \multirow{5}{*}{ Menentukan jenis-jenis sudut } & Mengidentifikasi & \multirow{5}{*}{1} \\
\hline & Menganalisis & \\
\hline & Menghubungkan & \\
\hline & Memecahkan masalah & \\
\hline & Mengevaluasi & \\
\hline \multirow{5}{*}{$\begin{array}{l}\text { Menentukan besar sudut-sudut berpelurus dan } \\
\text { berpenyiku }\end{array}$} & Mengidentifikasi & \multirow{5}{*}{2} \\
\hline & Menganalisis & \\
\hline & Menghubungkan & \\
\hline & Memecahkan masalah & \\
\hline & Mengevaluasi & \\
\hline \multirow{5}{*}{$\begin{array}{l}\text { Menentukan semua pasangan sudut yang terbentuk } \\
\text { jika dua garis sejajar dipotong garis lain }\end{array}$} & Mengidentifikasi & \multirow{5}{*}{3} \\
\hline & Menganalisis & \\
\hline & Menghubungkan & \\
\hline & Memecahkan masalah & \\
\hline & Mengevaluasi & \\
\hline \multirow{5}{*}{$\begin{array}{l}\text { Menentukan besar suatu sudut pada dua garis sejajar } \\
\text { yang dipotong garis lain jika diketahui besar sudut } \\
\text { yang lainnya }\end{array}$} & Mengidentifikasi & \multirow{5}{*}{5} \\
\hline & Menganalisis & \\
\hline & Menghubungkan & \\
\hline & Memecahkan masalah & \\
\hline & Mengevaluasi & \\
\hline Menerapkan berbagai konsep dan sifat-sifat garis dan & Mengidentifikasi & 4 \\
\hline
\end{tabular}




\begin{tabular}{|c|c|c|}
\hline \multirow[t]{4}{*}{ sudut dalam pemecahan masalah nyata } & Menganalisis & \\
\hline & Menghubungkan & \\
\hline & Memecahkan masalah & \\
\hline & Mengevaluasi & \\
\hline \multirow{5}{*}{ Penerapan konsep sudut dalam masalah nyata } & Mengidentifikasi & \multirow{5}{*}{6} \\
\hline & Menganalisis & \\
\hline & Menghubungkan & \\
\hline & Memecahkan masalah & \\
\hline & Mengevaluasi & \\
\hline
\end{tabular}
penskoran terhadap jawaban siswa pada setiap

Tabel 2.

Pedoman Penskoran Kemampuan Berpikir Kritis Siswa

\begin{tabular}{|c|c|c|}
\hline $\begin{array}{l}\text { Aspek yang } \\
\text { Diukur }\end{array}$ & Respon Siswa terhadap Soal & skor \\
\hline \multirow{4}{*}{ Menganalisis } & $\begin{array}{l}\text { Siswa tidak jelas dan tidak tepat mengidentifikasi informasi dan } \\
\text { permasalahan yang diketahui dan ditanyakan. }\end{array}$ & 1 \\
\hline & $\begin{array}{l}\text { Siswa kurang tepat mengidentifikasi informasi dan permasalahan } \\
\text { dengan cara menuliskan yang diketahui dan ditanyakan. }\end{array}$ & 2 \\
\hline & $\begin{array}{l}\text { Siswa dapat mengidentifikasi sebagian informasi dan permasalahan } \\
\text { dengan cara menuliskan yang diketahui dan ditanyakan. }\end{array}$ & 3 \\
\hline & $\begin{array}{l}\text { Siswa dapat mengidentifikasi seluruh informasi dan permasalahan } \\
\text { dengan cara menuliskan yang diketahui dan ditanyakan. }\end{array}$ & 4 \\
\hline \multirow{4}{*}{ Mengidentifikasi } & $\begin{array}{l}\text { Siswa tidak jelas dan tidak tepat dalam } \\
\text { konsep/definisi/teorema }\end{array}$ & 1 \\
\hline & $\begin{array}{l}\text { Siswa kurang tepat menentukan konsep/definisi/Teorema dalam } \\
\text { menyelesaikan permasalahan. }\end{array}$ & 2 \\
\hline & $\begin{array}{l}\text { Siswa dapat menentukan sebagian konsep/definisi/Teorema dalam } \\
\text { menyelesaikan permasalahan. }\end{array}$ & 3 \\
\hline & $\begin{array}{l}\text { Siswa dapat menentukan konsep/definisi/teorema dalam menyelesaikan } \\
\text { permasalahan dengan jelas dan tepat. }\end{array}$ & 4 \\
\hline \multirow{4}{*}{ Menghubungkan } & $\begin{array}{l}\text { Siswa tidak jelas dan tidak tepat dalam menerapkan } \\
\text { konsep/definisi/teorema }\end{array}$ & 1 \\
\hline & $\begin{array}{l}\text { Siswa kurang tepat menerapkan konsep/definisi/Teorema dalam } \\
\text { menyelesaikan permasalahan }\end{array}$ & 2 \\
\hline & $\begin{array}{l}\text { Siswa dapat menerapkan sebagian konsep/definisi/Teorema dalam } \\
\text { menyelesaikan permasalahan. }\end{array}$ & 3 \\
\hline & $\begin{array}{l}\text { Siswa dapat menerapkan konsep/definisi/teorema dalam menyelesaikan } \\
\text { masalah. }\end{array}$ & 4 \\
\hline \multirow{3}{*}{$\begin{array}{l}\text { Memecahkan } \\
\text { Masalah }\end{array}$} & $\begin{array}{l}\text { Siswa tidak jelas dan tidak tepat menunjukkan hasil utama dan prosedur } \\
\text { dalam penyelesaian masalah/penentuan solusi/jawaban. }\end{array}$ & 1 \\
\hline & $\begin{array}{l}\text { Siswa kurang tepat dalam menunjukkan hasil utama dan prosedur dalam } \\
\text { penyelesaian masalah/ penentuan solusi/jawaban. }\end{array}$ & 2 \\
\hline & Siswa dapat menunjukkan sebagian hasil utama dan prosedur dalam & 3 \\
\hline
\end{tabular}




\begin{tabular}{|l|l|c|}
\hline & penyelesaian masalah/penentuan solusi/jawaban. & \\
\cline { 2 - 3 } & $\begin{array}{l}\text { Siswa dapat menunjukkan hasil utama dan prosedur dalam penyelesaian } \\
\text { masalah/penentuan solusi/jawaban. }\end{array}$ & 4 \\
\hline & $\begin{array}{l}\text { Siswa tidak jelas dan tidak tepat menguji kembali jawaban dan } \\
\text { menentukan kesimpulan dari suatu permasalahan. }\end{array}$ & 1 \\
\cline { 2 - 3 } Mengevaluasi & $\begin{array}{l}\text { Siswa kurang tepat dalam menguji kembali jawaban dan menentukan } \\
\text { kesimpulan dari suatu permasalahan. }\end{array}$ & 2 \\
\cline { 2 - 3 } & $\begin{array}{l}\text { Siswa dapat menguji sebagian jawaban dan menentukan kesimpulan dari } \\
\text { suatu permasalahan. }\end{array}$ & 3 \\
\cline { 2 - 3 } & $\begin{array}{l}\text { Siswa dapat menguji kembali jawaban dan menentukan kesimpulan dari } \\
\text { suatu permasalahan. }\end{array}$ & 4 \\
\hline
\end{tabular}

Untuk memvalidasi instrumen digunakan validitas penilaian panelis (validitas konsep) validitas penilaian panelis mengunakan rumus Aiken:

dimana :

$$
V=\frac{\sum \eta_{i}\left|i-l_{o}\right|}{\mid N(c-1)]} \quad \text { (Aiken,1996: 91) }
$$

$\mathrm{V}=$ Indeks validitas isi

$n_{i}=$ Cacah dari titik skala hasil penilaian rater

$\mathrm{i}=$ Titik skala ke-I $(\mathrm{I}=1,2,3,4,5)$

$1_{\mathrm{o}}=$ Titik skala terendah

$\mathrm{N}=$ Jumlah rater $\left(\Sigma n_{i}\right)$

c = banyaknya titik skala Nilai $\mathrm{V}$ terletak antara 0 dan 1 (valid $\geq 0,6$ ).

Untuk mengetahui reliabilitas penilaian panelis dan hasil uji coba instrumen digunakan rumus Alpha sebagai berikut.

Keterangan:

$$
\alpha_{11}=\frac{k}{k-1}\left\{1-\frac{\sum S_{i}^{2}}{S_{t}^{2}}\right\}
$$

$\alpha_{11}=$ koefisien reliabilitas (reliabel $\geq 0,6$ )

$\mathrm{k}$ = banyak butir

$\mathrm{s}_{\mathrm{i}}^{2}=$ varians skor butir

$\mathrm{s}_{\mathrm{t}}^{2}=$ varian sskor total.

Selanjutnya dalam pemberian interpretasi terhadap koefisien reliabilitas tes $\left(\alpha_{11}\right)$ pada umumnya digunakan patokan:

$$
\begin{aligned}
& 0,00<\alpha_{11} \leq 0,20 \text { reliabilitas : sangat } \\
& \text { rendah }
\end{aligned}
$$

$0,20<\alpha_{11} \leq 0,40 \quad$ reliabilitas : rendah

$0,40<\alpha_{11} \leq 0,70 \quad$ reliabilitas : sedang

$0,70<\alpha_{11} \leq 0,90$ reliabilitas : tinggi

$0,90<\alpha_{11} \leq 1,00$ reliabilitas : sangat tinggi

Pengumpulan data dalam penelitian ini dilakukan dengan pemberian instrumen tes Kemampuan Berpikir Kritis dan tes Kemampuan Berpikir Kritis matematik dalam bentuk essay kepada siswa. Lembar jawaban siswa diberi skor yang disuaikan dengan indikator Kemampuan Berpikir Kritis siswa. Hasil pekerjaan siswa akan dikumpulkan oleh Peneliti untuk diperiksa dan diberi skor sesuai rubrik penilaian kemampuan berpikir kritis dapat di lihat pada lampiran 6. Skor perolehan siswa kemudian dikonversi ke skala 100 dengan aturan:

$$
\begin{aligned}
& \text { Nilai perolehan siswa }= \\
& \frac{\text { skor perolehan siswa }}{\text { skor maksimal }} \times 100
\end{aligned}
$$

Nilai perolehan siswa tersebut merupakan data dalam penelitian ini. Skor perolehan siswa secara keseluruhan dapat di lihat pada lampiran 7.

Kriteria hasil kemampuan berpikir kritis siswa yang digunakan adalah menurut A. Setyowati dalam Jurnal Pendidikan Fisika 
Indonesia 7 (2011: 89-96) dapat di lihat pada tabel 3. berikut:

Tabel 3.

Kriteria Kemampuan Berpikir Kritis Siswa

\begin{tabular}{|c|c|}
\hline Rentang Nilai & Kriteria \\
\hline $81,25-100$ & Sangat Kritis \\
\hline $62,50-81,25$ & Kritis \\
\hline $43,75-62,50$ & Kurang Kritis \\
\hline $25,00-43,75$ & Sangat Kurang Kritis \\
\hline
\end{tabular}

Dalam menganalisis data menggunakan analisis deskriptif untuk memperoleh angka dalam bentuk Persentase Kemampuan Berpikir Kritis Siswa dalam menyelesaikan soal dengan materi garis dan sudut pada siswa kelas VII-d SMP Negeri 7 Kendari.

\section{Hasil}

Penelitian ini dilaksanakan di SMP Negeri 7 Kendari, dengan Subjek dalam penelitian ini ialah kelas VII-d yang terdiri dari 24 siswa yang mengikuti tes kemampuan berpikir kritis. Penelitian ini dilakukan untuk mengetahui Kemampuan Berpikir Kritis siswa pada materi garis dan sudut kelas VII-d SMP Negeri 7 Kendari Tahun Ajaran 2017/2018. Instrumen penelitian ini terdiri atas 6 soal yang mewakili indikator-indikator Kemampuan Berpikir Kritis pada materi garis dan sudut.

Data Kemampun Berpikir Kritis Siswa Kelas VII-d SMP Negeri 7 Kendari Kelurahan Anggalomelai Kecamatan Abeli Kota Kendari diperoleh dari Hasil Tes Kemampuan Berpikir Kritis Siswa Pada Materi Garis Dan Sudut Kelas VII-d SMP Negeri 7 Kendari, dan diketahui bahwa sebagian besar kemampuan berpikir kritis siswa pada materi garis dan sudut kelas VII-d SMP Negeri 7 Kendari berada pada kriteria kurang kritis yaitu pada Rentang 43,75 - 62,50 sampai dengan kriteria sangat kurang kritis yaitu pada Rentang 25,00 - 43,75.

Berikut ini pekerjaan siswa yang masuk pada kategori sangat kritis, dimana siswa dapat menganalisis informasi permasalahan dengan cara menuliskan yang diketahui dan ditanyakan serta siswa dapat menunjukan hasil utama sekaligus prosedur dalam penyelesaian solusi/jawaban.

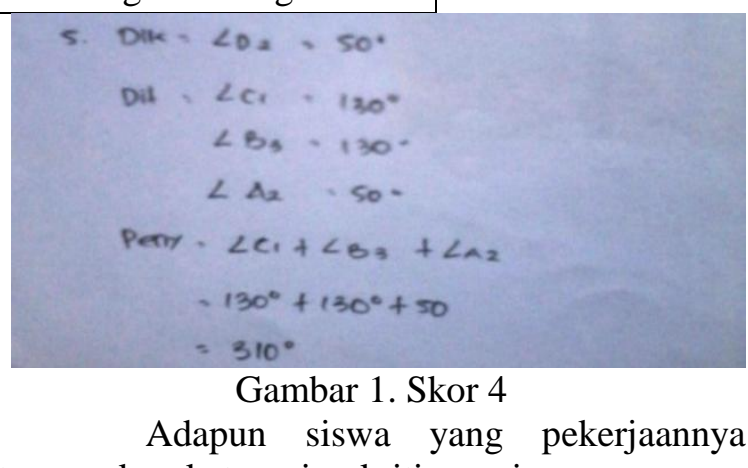
termasuk kategori kritis, siswa mampu menuliskan sebagian informasi permasalahan dengan cara tidak menuliskan yang diketahui dan ditanyakan namun siswa dapat menunjukan hasil utama dalam penyelesaian solusi/jawaban.

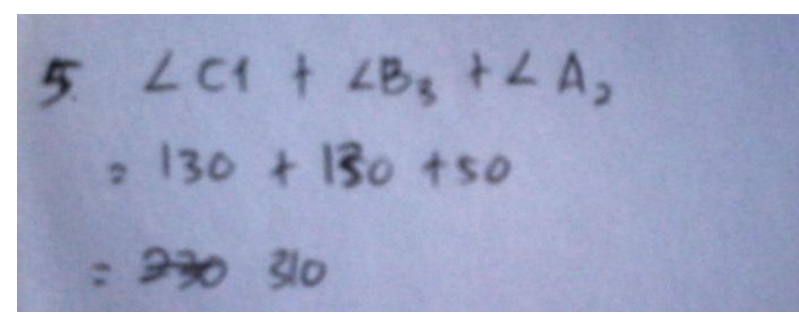

Gambar 2. Skor 2

Untuk siswa yang pekerjaanya masuk kategori sangat kurang kritis, siswa dalam mengidentifikasi soal tidak jelas, tidak tepat dan tidak lengkap serta siswa dalam menunjukan hasil pekerjaannya tidak jelas dan tidak tepat.

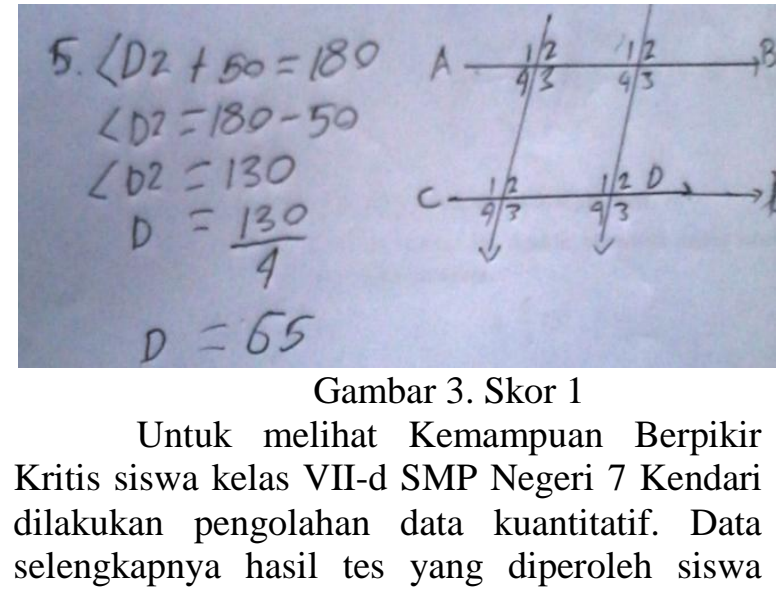


pada setiap butir soal materi garis dan sudut kelas VII-d SMP Negeri 7 Kendari Tahun
Pelajaran 2017/2018 ditabulasikan dalam tabel berikut:

Tabel 4

Distribusi Skor Hasil Tes Yang Diperoleh Siswa Pada Setiap Butir Soal

\begin{tabular}{|c|c|c|c|c|c|c|c|c|c|}
\hline \multirow{2}{*}{ No. } & \multirow{2}{*}{ Nama Siswa } & \multicolumn{6}{|c|}{$\begin{array}{c}\text { Hasil Tes Kemampuan Berpikir } \\
\text { Kritis Siswa }\end{array}$} & \multirow{2}{*}{ Nilai } & \multirow{2}{*}{ Kriteria } \\
\hline & & 1 & 2 & 3 & 4 & 5 & 6 & & \\
\hline 1 & Subjek 1 & 4 & 3 & 4 & 1 & 2 & 4 & 75,0 & Kritis \\
\hline 2 & Subjek 2 & 4 & 4 & 1 & 4 & 4 & 4 & 87,5 & Sangat Kritis \\
\hline 3 & Subjek 3 & 3 & 2 & 4 & 3 & 2 & 4 & 75,0 & Kritis \\
\hline 4 & Subjek 4 & 4 & 3 & 4 & 3 & 2 & 4 & 83,3 & Sangat Kritis \\
\hline 5 & Subjek 5 & 4 & 3 & 4 & 2 & 1 & 4 & 75,0 & Kritis \\
\hline 6 & Subjek 6 & 3 & 1 & 4 & 1 & 2 & 4 & 62,5 & Kritis \\
\hline 7 & Subjek 7 & 3 & 1 & 3 & 1 & 1 & 2 & 45,8 & Kurang Kritis \\
\hline 8 & Subjek 8 & 4 & 4 & 3 & 2 & 1 & 1 & 62,5 & Kritis \\
\hline 9 & Subjek 9 & 3 & 1 & 4 & 3 & 2 & 2 & 62,5 & Kritis \\
\hline 10 & Subjek 10 & 1 & 1 & 4 & 1 & 1 & 3 & 45,8 & Kurang Kritis \\
\hline 11 & Subjek 11 & 1 & 1 & 3 & 1 & 1 & 3 & 41,7 & Sangat Kurang Kritis \\
\hline 12 & Subjek 12 & 3 & 2 & 1 & 1 & 1 & 3 & 45,8 & Kurang Kritis \\
\hline 13 & Subjek 13 & 2 & 1 & 4 & 1 & 1 & 3 & $\mathbf{5 0 , 0}$ & Kurang Kritis \\
\hline 14 & Subjek 14 & 2 & 1 & 3 & 1 & 1 & 3 & 45,8 & Kurang Kritis \\
\hline 15 & Subjek 15 & 3 & 1 & 1 & 1 & 1 & 4 & 45,8 & Kurang Kritis \\
\hline 16 & Subjek 16 & 1 & 1 & 1 & 1 & 1 & 1 & 25,0 & Sangat Kurang Kritis \\
\hline 17 & Subjek 17 & 4 & 2 & 4 & 1 & 1 & 4 & 66,7 & Kritis \\
\hline 18 & Subjek 18 & 4 & 3 & 4 & 1 & 1 & 2 & 62,5 & Kritis \\
\hline 19 & Subjek 19 & 2 & 1 & 4 & 1 & 1 & 2 & 45,8 & Kurang Kritis \\
\hline 20 & Subjek 20 & 2 & 2 & 4 & 1 & 1 & 2 & 50,0 & Kurang Kritis \\
\hline 21 & Subjek 21 & 1 & 2 & 1 & 1 & 1 & 1 & 29,2 & Sangat Kurang Kritis \\
\hline 22 & Subjek 22 & 2 & 2 & 1 & 1 & 2 & 3 & 45,8 & Kurang Kritis \\
\hline 23 & Subjek 23 & 4 & 4 & 4 & 4 & 4 & 4 & 100,0 & Sangat Kritis \\
\hline 24 & Subjek 24 & 3 & 1 & 3 & 1 & 1 & 3 & $\mathbf{5 0 , 0}$ & Kurang Kritis \\
\hline
\end{tabular}

Dari tabel terlihat bahwa hasil perhitungan dengan bantuan Microsoft Excel 2007 diperoleh Nilai Siswa Kelas VII-d SMP Negeri 7 Kendari terdapat 3 siswa atau $12 \%$ berada pada kriteria sangat kritis, 8 Siswa atau $32 \%$ berada pada kriteria Kritis, 10 siswa atau

$40 \%$ berada pada kriteria Kurang Kritis, dan 3 siswa atau $12 \%$ berada pada kriteria Sangat kurang Kritis. Agar lebih jelas Kriteria nilai Kemampuan Berpikir Kritis siswa pada materi garis dan sudut kelas VII-d SMP Negeri 7 Kendari dapat dilihat pada tabel berikut. 
Tabel 5 .

Kriteria Tingkat Kemampuan Berpikir Kritis Siswa Pada Materi Garis dan Sudut Kelas VII-d SMP Negeri 7 Kendari

\begin{tabular}{|c|c|c|}
\hline Rentang Nilai & $\begin{array}{c}\text { Jumlah Siswa / } \\
\text { Persentase }\end{array}$ & Kriteria \\
\hline $81,25-100$ & $3(12 \%)$ & Sangat Kritis \\
\hline $62,50-81,25$ & $8(32 \%)$ & Kritis \\
\hline $43,75-62,50$ & $10(40 \%)$ & Kurang Kritis \\
\hline $25,00-43,75$ & $3(12 \%)$ & Sangat Kurang Kritis \\
\hline
\end{tabular}

\section{Pembahasan}

Dari hasil penelitian yang telah dilakukan, dapat diketahui dengan jelas bahwa siswa-siswi kelas VII-d SMP Negeri 7 Kendari memiliki Kemampuan Berpikir Kritis berada pada kriteria kurang kritis. Hal ini dapat dilihat dari kemampuan siswa dalam menyelesaikan soal yang menjadi butir tes dalam penelitian.

Hasil penelitian menunjukkan bahwa dari 24 siswa yang mengikuti tes diperoleh keterangan 3 siswa memiliki Kemampuan Berpikir Kritis berada pada kriteria sangat kritis, 8 siswa memiliki Kemampuan Berpikir Kritis berada pada kriteria Kritis, 10 siswa memiliki Kemampuan Berpikir Kritis berada pada kriteria kurang Kritis, dan 3 siswa memiliki Kemampuan Berpikir Kritis berada pada kriteria sangat kurang Kritis. Hal ini dapat dikatakan bahwa sebagian besar siswa-siswi kelas VII-d SMP Negeri 7 Kendari sudah memiliki Kemampuan Berpikir Kritis.

Jika dilihat dari hasil persentase diperoleh keterangan bahwa $12 \%$ siswa memiliki Kemampuan Berpikir Kritis sangat tinggi, 32\% siswa memiliki Kemampuan Berpikir Kritis tinggi, 40\% siswa memiliki Kemampuan Berpikir Kritis kurang kritis, 12\% siswa memiliki kemampuan berpikir ktitis sangat kurang kritis.

Jika dilihat dari bentuk soal tes, diperoleh keterangan bahwa dari 24 siswa-siswi kelas VII-d SMP Negeri 7 Kendari yang mengikuti tes, 12 siswa mampu menyelesaikan soal yang indikatornya mengidentifikasi, 9 siswa mampu menyelesaikan soal yang indikatornya menghubungkan, 6 siswa mampu menyelesaikan soal yang indikatornya menganalisis, 11 siswa mampu menyelesaikan soal yang indikatornya memecahkan masalah, dan 2 siswa yang mampu menyelesaikan soal yang indikatornya mengevaluasi.

Jika dilihat dari banyaknya indikator yang mampu diselesaikan, diperoleh keterangan bahwa dari 24 siswa-siswi kelas VII-d SMP Negeri 7 Kendari yang mengikuti tes, 16 siswa mampu menyelesaikan 1 indikator, 4 siswa mampu menyelesaikan 2 indikator, 4 siswa mampu menyelesaikan 3 indikator, 2 Siswa mampu menyelesaikan 4 indikator, dan 3 siswa mampu menyelesaikan 5 indikator.

\section{Simpulan dan Saran}

\section{Simpulan}

Berdasarkan hasil analisis data dan pembahasan yang telah dikemukakan pada bab sebelumnya, peneliti menyimpulkan bahwa hasil tes Kemampuan Berpikir Kritis siswa kelas VIId pada materi garis dan sudut SMP Negeri 7 Kendari menunjukan bahwa terdapat 3 siswa atau $12 \%$ berada pada kriteria sangat kritis, 8 Siswa atau $32 \%$ berada pada kriteria Kritis, 10 siswa atau $40 \%$ berada pada kriteria Kurang Kritis, dan 3 siswa atau $12 \%$ berada pada kriteria Sangat kurang Kritis. Dari 24 siswasiswi kelas VII-d SMP Negeri 7 Kendari yang mengikuti tes, 12 siswa mampu menyelesaikan soal yang indikatornya mengidentifikasi, 9 siswa mampu menyelesaikan soal yang indikatornya menghubungkan, 6 siswa mampu menyelesaikan soal yang indikatornya menganalisis, 11 siswa mampu menyelesaikan soal yang indikatornya memecahkan masalah, dan 2 siswa yang mampu menyelesaikan soal yang indikatornya mengevaluasi. Sehingga dapat dikatakan siswasiswi kelas VII-d SMP Negeri 7 Kendari sudah memiliki kemampuan untuk berpikir kritis namun kurang pada indikator menganalisis dan sangat kurang pada indikator mengevaluasi. 
Saran

Berdasarkan hasil pembahasan dan kesimpulan, maka penulis menyarankan agar guru hendaknya lebih memperhatikan kemampuan berpikir siswa terutama Kemampuan Berpikir Kritis yang dimiliki siswa pada indikator menganalisis dan pada indikator mengevaluasi. Selain itu, guru hendaknya lebih memotivasi siswa berpikir kritis dan memilih model atau metode pembelajaran yang sesuai dengan karakter siswa dalam hal ini fakor-faktor yang dapat menunjang keberhasilan siswa dalam belajar dan membantu siswa dalam mengembangkan Kemampuan Berpikir Kritis yang dimilikinya sehingga tujuan pembelajaran dapat tercapai dengan hasil yang memuaskan.

\section{Daftar Pustaka}

Suherman, (2008). Definisi Belajar. Tersedia di: http://bbawor.blogspot.com/ Definisi_hasil_belajar.html [3 Oktober 2017].

Soekamto (1997). Teori Belajar dan ModelModel Pembelajaran. Jakarta: Dirjen Dikti-Depdikbud.

Johnson , E. (2000). Technology Enhanced Learning Environtments that are Conducive to Critical Thinking in Mathematics: Implications for Research about Critical Thinking on the World Wide Web. [online].

Ruggiero, Asri. (2007). Pembelajaran Berbasis Masalah Terbuka dan Terstruktur Dalam Upaya Meningkatkan Kemampuan Berpikir Matematik Tingkat Tinggi Siswa SMP. Skripsi FPMIPA UPI. [online]. Tersedia di: http://etd.eprints.ums.ac.id/1631/1/A4 10030035.pdf [8 Januari 2017]

Susanto, (2015). Applying mathemathics education (RME) in teaching geometry in indonesia primary schools. Tesis Master, University of Twete,Ducth.

Trianto. (2007). Model-model Pembelajaran Inovatif Berorientasi Konstruktivistik. Jakarta: Pustaka Publisher.
Iskandar. (2009). Psikologi Pendidikan Sebuah Orientasi Baru. Jakarta: Gaung Persada Press.

Rosyada, Dede. (2004). Paradigma Pendidikan Demokratis Sebuah Modal Masyarakat dalam Penyelenggaraan Pendidikan. Jakarta: Prenada Media.

Hassoubah, Z. I. (2007). Mengasah Pikiran Kreatif dan Kritis: Disertai Ilustrasi dan Latihan. Bandung: Nuansa.

Murti, Bhisma. (2009). Berpikir Kritis(Critical Thinking). Seri Kuliah Budaya Ilmiah.

Fakultas Kedokteran Universitas Sebelas Maret. [Online].Tersedia di: http://researchengenis.com. pada tanggal 6 Januari 2017.

Emir, S. (2013). Contribusing of Teacher's Thinking Styles to Critical Thinking Dispositions (Istanbul-Fatih Sample). Educational Sciences: Theory \& Practice, 13(1): 337-347.

Ennis, Robert H. (1996). Critical Thingking. New jersey: prentice - Hall, Inc. [online]. Tersedia di: http://faculty.ed.uiuc.edu/rhennis.html. [20 Januari 2013].

Ismaimuza, Dasa. (2010). Kemampuan Berpikir Kritis dan Kreatif Matematis Siswa SMP Melalui Pembelajaran Berbasis Masalah dengan Strategi Konflik Kognitif. Disertasi pada PPs UPI.Tidak Dipublikasi.

Kemendikbud. (2013). Materi Pelatihan Guru Implementasi Kurikulum 2013: SMA Matematika. Jakarta: Kemendikbud.

Mahmuzah R. (2015).Peningkatan Kemampuan Berpikir Kritis Matematis Siswa SMP Melalui Pendekatan Problem Posing.

Masrukan \& Rochmad. (2014). Teaching and Learning Mathematics Using Four-K Model at Junior High School. Artikel. Semarang: Universitas Negeri Semarang.

Masrukan, Rochmad, B.E. Susilo, \& Suhito. (2014). Pengembangan Pembelajaran Matematika Bermuatan Pendidikan Karakter dan Ekonomi Kreatif Berbantuan Alat Peraga Barang Bekas dengan Asesmen Kinerja. Laporan Kemajuan Penelitian 
Unggulan Perguruan Tinggi.

Semarang: Universitas Negeri

Semarang.

Mayadiana, D. (2005). Pembelajaran dengan Pendekatan Diskursif untuk Meningkatkan Kemampuan berpikir kritis matematik Mahasiswa calon guru Sekolah Dasar. Tesis pada PPS UPI: Tidak diterbitkan.

Purwati R. (2016) Analisis Kemampuan Berpikir Kritis Siswa Dalam Menyelesaikan Masalah Persamaan Kuadrat Pada Pembelajaran Model Creative Problem Solving

Sudaryanto.( 2011). Kajian kritis tentang permasalahan sekitar pembelajaran kemampuan berpikir kritis. Tersedia di:

http://www.fk.undip.ac.id/pengemban gan-pendidikan/77-pembelajarankemampuan-berpikir-kritis.html.

Sugiyono. (2013). Metode Penelitian Pendidikan (Pendekatan Kuantitatif, Kualitatif, dan $R$ \& D). Bandung: Alfabeta.

Sumarmo, U. (2010). Berpikir dan Disposisi Matematik: Apa, Mengapa, dan Bagaimana Dikembangkan pada Peserta Didik.FPMIPA UPI Bandung. Tersedia di: http://math.sps.upi.edu [20 Januari 2017].

Ulya, H. (2014). Analisis Kemampuan Pemecahan Masalah Matematika SMP Ditinjau dari Gaya Kognitif Siswa. Tesis. Universitas Negeri Semarang. 